\title{
Fenologi Pembungaan dan Penyerbukan Cereus jamacaru D.C. (Cactaceae) Koleksi Kebun Raya Bogor
}

\section{Flowering Phenology and Pollination of Cereus jamacaru D.C. (Cactaceae) Bogor Botanic Gardens Collection}

\author{
Elly Kristiati Agustin dan R. Vitri Garvita*
}

Pusat Penelitian Konservasi Tumbuhan dan Kebun Raya-LIPI

J1. Ir. H. Junada No.13, Bogor 16122, Indonesia

Diterima 22 Oktober 2020/Disetujui 29 Maret 2021

\begin{abstract}
Cactaceae is a native American (North. Central, and South) plant in tropical and temperate, ecologically very important in dry and arid ecosystems. Cereus jamacaru D.C. (Pleated cereus) is considered important because of its potential as an ornamental flower, food, and medicine. The flowering and fruiting phenology of this plant is still not widely known. This study aimed to determine the phenology stages of flowering and fruiting of $\underline{C}$. jamacaru, and also to determine the pollinators that play a role in the pollination process. This research was conducted in Bogor Botanical Gardens in March-May 2015. The number of samples observed was seven flower buds (inflorescence). The observations were included the phenology of flower blooming (stage 1) and anthesis (stage 2). The variables observed in stage 1 were the length and diameter of the flower and fruit buds, also the bud tube diameter. The variables observed in stage 2 were the length of the florets, the diameter of perianthium, and the diameter of stamens. The results showed that in stage 1, the length of flower buds was 98.35 mm, diameter of flower buds was $42.95 \mathrm{~mm}$, length of fruit was $47.79 \mathrm{~mm}$, diameter of fruit was $20.83 \mathrm{~mm}$ and diameter of flower buds tube was $17.96 \mathrm{~mm}$. In stage 2 after anthesis, the diameter of stamens was $40.26 \mathrm{~mm}$, diameter of perianthium was 80.11 $\mathrm{mm}$, and length of the florets was $176.77 \mathrm{~mm}$. The pollinators are Trigona, Apis indica and ants.
\end{abstract}

Keywords: cactus, Cereus jamacaru, reproductive biology, pollination, flowering

\section{ABSTRAK}

Cactaceae merupakan tanaman asli Amerika (bagian Utara, Tengah dan Selatan) daerah tropis dan subtropis, berperan penting dalam ekosistem kering dan gersang. Tanaman Cereus jamacaru D.C. (Pleated cereus) dianggap penting karena berpotensi sebagai bunga hias, makanan dan obat. Fenologi pembungaan dan pembuahan tanaman ini belum banyak

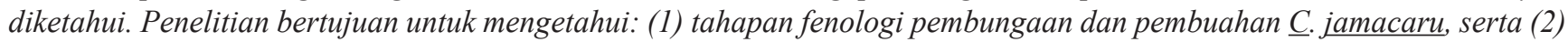
polinator yang berperan dalam proses penyerbukan. Penelitian dilakukan di Kebun Raya Bogor pada bulan Maret - Mei 2015. Jumlah sampel yang diamati adalah tujuh kuncup bunga (inflorescens). Pengamatan meliputi fenologi pemekaran bunga (tahap 1) dan bunga mekar sempurna (tahap 2). Variabel yang diamati pada tahap 1 adalah panjang dan diameter kuncup bunga, panjang dan diameter calon buah, serta diameter tabung kuntum. Variabel yang diamati pada tahap 2 adalah panjang kuntum, diameter periantum, dan diameter kumpulan stamen. Hasil penelitian menunjukkan bahwa pada tahap 1, panjang kuncup bunga $98.35 \mathrm{~mm}$, diameter kuncup bunga $42.95 \mathrm{~mm}$, panjang calon buah $47.79 \mathrm{~mm}$, diameter calon buah $20.83 \mathrm{~mm}$ dan diameter tabung kuntum $17.96 \mathrm{~mm}$. Pada tahap 2 setelah antesis, diameter kumpulan stamen $40.26 \mathrm{~mm}$, diameter periantum $80.11 \mathrm{~mm}$ dan panjang kuntum $176.77 \mathrm{~mm}$. Polinator penyerbukan yaitu Trigona, Apis indica, dan semut.

Kata kunci: kaktus, biologi reproduksi, penyerbukan, pemekaran

\section{PENDAHULUAN}

Spesies Cereus jamacaru D.C. termasuk dalam genus Cereus yang memiliki kurang lebih 35 spesies (Anderson,

\footnotetext{
* Penulis untuk korespondensi. e-mail: gandadikusumahvitri692@ gmail.com
}

2001). Tanaman ini berasal dari Brazil dengan nama lokal "mandacaru/cardeiro" dan banyak ditemukan di daerah kering (Franck et al., 2017). Masyarakat lokal Brasil memanfaatkannya sebagai makanan dan obat tradisional untuk mengobati infeksi saluran kemih, peradangan pada ginjal, rematik, dan sebagai antioksidan (de Lucena et al., 2013). Persebaran tanaman ini meliputi Brazil, Mexico, 
Hindia Barat, Paraguay, Peru, Pukulaica, dan Uruguay (Sutton, 2017).

Tanaman Cereus jamacaru (Gambar 1) memiliki morfologi seperti pohon dengan batang tegak, tinggi dapat mencapai $10 \mathrm{~m}$ dan diameter batang mencapai $60 \mathrm{~cm}$ (Meiado et al., 2010). Batang berwarna hijau dan terdapat banyak duri dengan ukuran 2-3 cm. Bunga soliter dan berwarna putih berbentuk corong dengan diameter $21-30 \mathrm{~cm}$, panjang $15-20 \mathrm{~cm}$. Pericarpel dan hypanthium hingga $16 \mathrm{~cm}$; hijau, berskala kecil, merah atau kemerahan. Buah ellipsoid, 6-10 $\mathrm{cm} \times 4-8 \mathrm{~cm}$, merah tua sampai merah muda. Biji berukuran kecil berwarna hitam, tumbuh ke atas dengan percabangan yang banyak dan berduri kayu. Bunga bersifat heteromorfik yaitu letak benang sari tidak sejajar dengan putik, memiliki ovarium bersisik, stamen dengan panjang yang bervariasi dan berjumlah banyak serta stigma berbentuk linear dengan cabang berjumlah 13-15. Perhiasan bunga bagian luar lebih tebal dengan ujung membundar berwarna kemerahan kelam. Perhiasan bunga bangian dalam lebih tipis seperti mahkota, berwarna putih. Bunga akan gugur setelah antesis (Britton dan Rose, 1920; Jordaan and Mantji, 2012).

Pengetahuan mengenai reproduksi biologi $C$.jamacaru masih sangat terbatas seperti morfologi, fisiologi, biokimia, dan etnobotani. Salah satu faktor yang menentukan

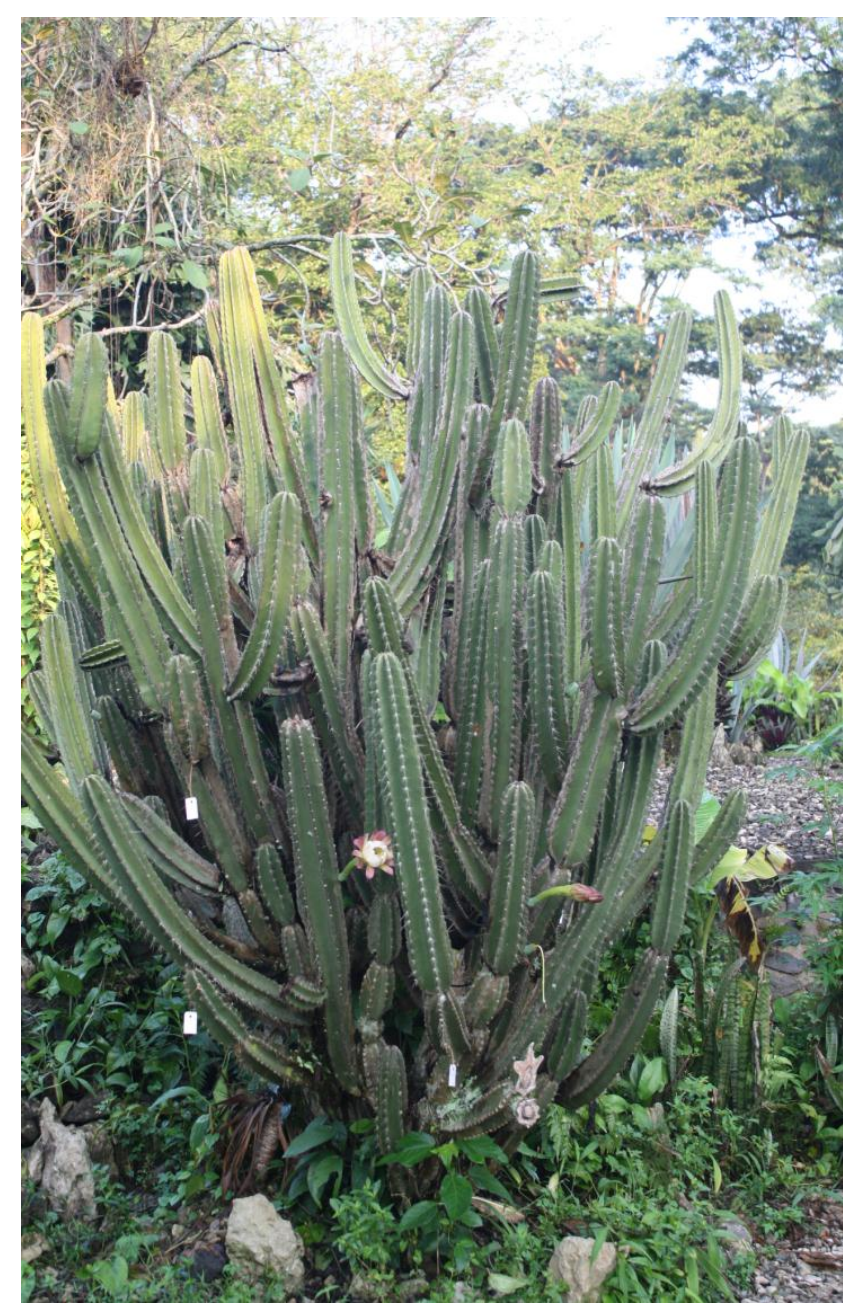

Gambar 1. Habitus Cereus jamacaru keberhasilan reproduksi suatu tanaman adalah waktu berbunga. Fenologi perbungaan yang terjadi secara periodik pada setiap tumbuhan memiliki karakter dan perilaku yang berbeda-beda, serta dipengaruhi oleh faktor lingkungan seperti penyinaran, suhu, dan kelembaban udara. Pada fase perbungaan terjadi proses awal bagi suatu tumbuhan untuk berkembang biak yang diawali dengan pemunculan kuncup bunga dan diakhiri dengan pematangan buah. Berdasarkan hasil penelitian Dutra et al. (2019), tahapan pembuahan pada C. jamacaru sangat berperan penting dalam proses produksi flavonoid. Ekstrak cladode buah $C$. jamacaru dengan kandungan flavonoid yang tinggi dapat dimanfaatkan sebagai antioksidan alami dan antikanker. Penyerbukan memiliki peranan yang sangat penting pada serangkaian proses fenologi pembungaan dan pembuahan suatu tanaman. Buah yang masak dikonsumsi oleh kelalawar di malam hari dan burung pada siang hari, karena buah tersebut banyak mengandung air, kaya akan karbohidrat, serta rendah protein dan lemak (Gomes et al., 2014).

Informasi mengenai morfologi bunga dan biologi reproduksi pada tanaman kaktus epifit masih sangat terbatas. Hal ini dapat disebabkan oleh terbatasnya periode pembungaan (waktu berbunga), fenologi bunga yang masih belum banyak dipahami dan kesulitan melakukan studi lapangan tanaman ini. Keberhasilan dalam bereproduksi suatu tanaman sangat dipengaruhi oleh saat waktunya berbunga, contohnya berbunga pada waktu yang kurang tepat sehingga bunga tersebut tidak dikunjungi oleh hewan penyerbuk. Penelitian ini diharapkan dapat memberikan informasi mengenai masa waktu berbunga dan fenologi bunga.

Penyerbukan memiliki peranan yang sangat penting dalam meningkatkan kualitas dan kuantitas produk hortikultura termasuk tanaman hias. Penyerbukan yang dibantu oleh serangga dapat meningkatkan produktivitas buah. Penyerbukan yang terjadi dengan bantuan serangga disebut Entomogami. Penelitian ini bertujuan untuk mengetahui tahapan fenologi pembungaan dan pembuahan C. jamacaru, serta untuk mengetahui polinator yang berperan dalam proses penyerbukan.

\section{BAHAN DAN METODE}

Penelitian ini dilaksanakan pada bulan Maret sampai Mei 2015 di Kebun Raya Bogor. Bahan tanaman yang digunakan merupakan koleksi Kebun Raya Bogor yaitu $C$. jamacaru DC. Alat yang digunakan adalah jangka sorong, meteran, pensil, label dan kamera. Sampel pohon yang diamati terdiri atas 2 spesimen, berumur 20 tahun. Pada pohon nomor 1 sampel pengamatan terdiri atas 4 kuncup yang terdapat pada 4 cabang, sedangkan pada pohon nomor 2 pengamatan dilakukan pada tiga cabang untuk 3 kuncup bunga. Total kuncup bunga yang diamati adalah tujuh kuncup bunga $C$. jamacaru. Pemilihan kuncup dilakukan secara acak. Cabang yang diamati dipastikan memiliki kuncup bunga yang akan berkembang menjadi bunga. Masing-masing sampel diberi label, yang berisi identitas tanggal munculnya kuncup bunga dan nomor sampel. 
Pengamatan fenologi pembungaan dan pembuahan dilakukan sejak munculnya tunas bunga sampai bunga mekar (antesis) kemudian gugur dan terbentuk buah. Pengamatan dilakukan setiap hari pada saat kuncup bunga dan dilanjutkan malam hari pada saat bunga akan mekar.

Dalam penelitian ini, dilakukan dua tahap pengamatan, yaitu: (1) pengamatan fenologi pemekaran bunga dan (2) pengamatan bunga mekar sempurna dapat dilihat pada Gambar 2.

\section{Pengamatan Fenologi Pemekaran Bunga}

Pertumbuhan dan perkembangan bunga diamati dengan peubah panjang kuncup, diameter kuncup, diameter tabung kuntum, panjang calon buah dan diameter calon buah. Panjang kuntum diukur dari pangkal bakal bunga yang menempel pada batang kaktus sampai ujung kuntum. Pengamatan dilakukan setiap hari sampai bunga gugur. Tabung bunga diukur dari pangkal kuntum bunga sampai ke bagian pangkal kuncup bunga.

\section{Pengamatan Bunga Mekar Sempurna}

Pengamatan fenologi pemekaran bunga dilakukan mulai pukul 18.00 WIB ketika kuncup bersifat simetri zigomorf (simetri cermin). Pengamatan dilakukan setiap selang 2 jam yaitu pada pukul $18.00 ; 20.00 ; 22.00 ; 24.00$; 02.00; 04.00-06.00 WIB. Variabel yang diamati adalah panjang kuntum, diameter periantium, dan diameter kumpulan stamen (benangsari). Pada pemekaran bunga yang terjadi malam hari dicatat juga serangga pengunjung yang membantu penyerbukan bunga $C$. jamacaru.

\section{HASIL DAN PEMBAHASAN}

Hasil pengamatan menunjukkan bahwa fenologi bunga $C$. jamacaru membutuhkan waktu sekitar 14-15 hari, diawali dengan munculnya bakal kuncup bunga, bunga mekar sempurna (antesis) sampai dengan gugur. Bagianbagian bunga dapat dilihat pada Gambar 3. Dalam satu kumpulan stamen terdiri atas 450-550 stamen (Gambar 3D). Berdasarkan pengamatan, Cereus jamacaru mekar sempurna pada malam hari kemudian menutup kembali pada pagi hari dan gugur jika tidak terjadi pembuahan. Pentingnya mempelajari pembungaan pada C. jamacaru adalah untuk mengetahui periode masa panen buah. Tanaman ini berbunga pada malam hari, wangi, bunganya berwarna putih, besar dan hanya bertahan selama satu hari. Perianthium merupakan kelopak bunga (calyx) yang berperan sebagai perhiasan bunga, secara morfologi bagian ini merupakan modifikasi dari daun. Secara morfologi, perianthium berfungsi menutup bunga yang belum siap

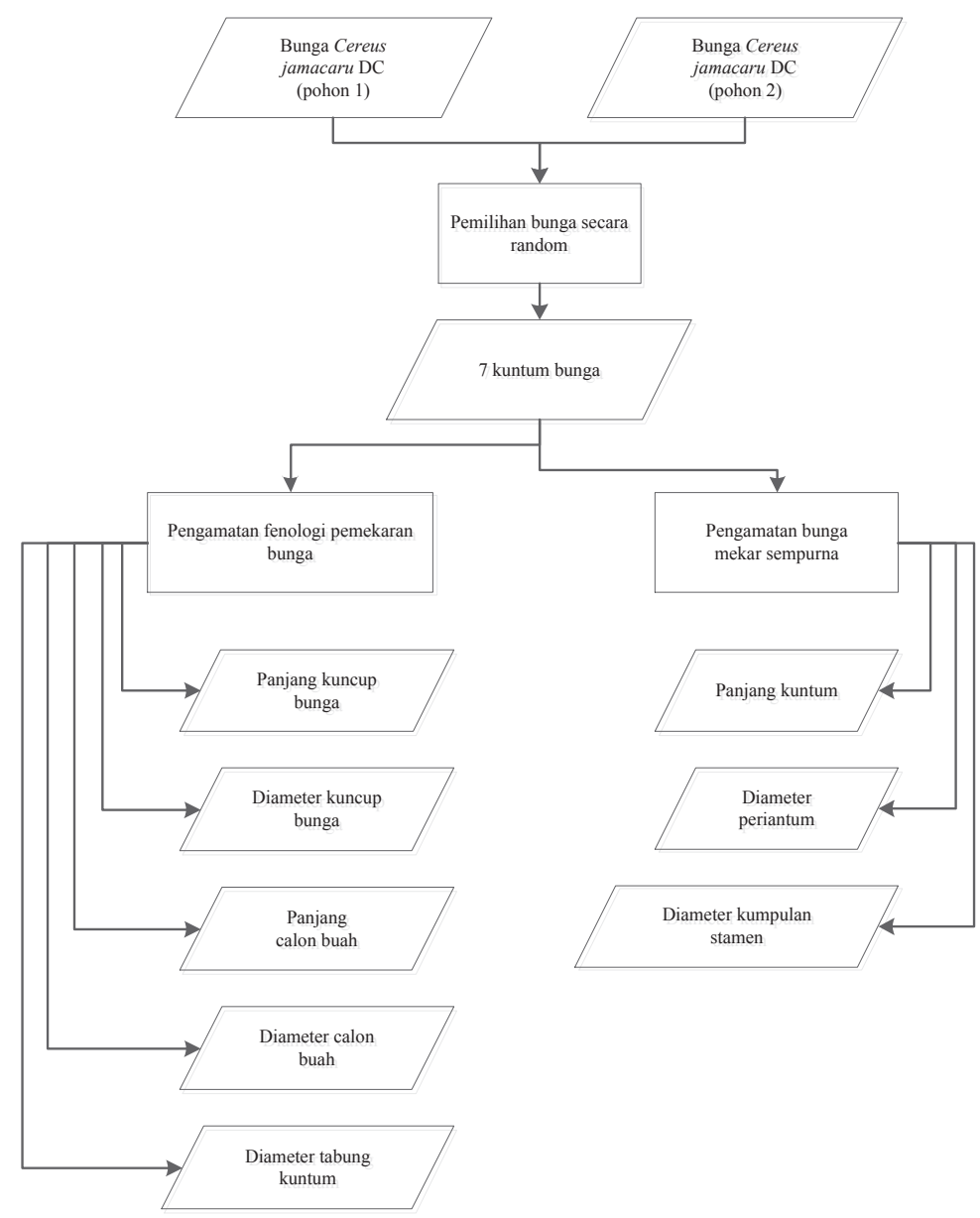

Gambar 2. Diagram alir pengamatan fenologi pemekaran bunga dan bunga mekar sempurna 


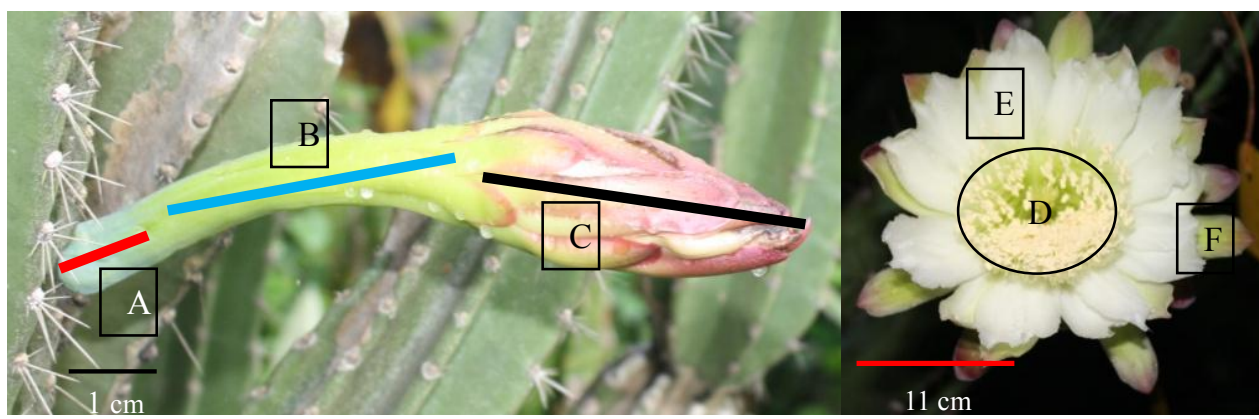

Gambar 3. Bagian bagian bunga C. jamacaru (A) calon buah, (B) tabung bunga, (C) kuncup bunga, (D) kumpulan stamen, (E) periantium dalam, (F) periantium luar

untuk mekar dan menarik perhatian serangga penyerbuk. Antesis merupakan suatu periode dimana bunga telah mekar sempurna dan berfungsi maksimal.

Hasil pengamatan pada hari ke-12 atau hari menjelang mekar sempurna menunjukkan bahwa variabel panjang kuncup bunga mencapai $98.35 \mathrm{~mm}$, diameter kuncup bunga mencapai $42.95 \mathrm{~mm}$, panjang calon buah mencapai $47.79 \mathrm{~mm}$, diameter calon buah $20.83 \mathrm{~mm}$ serta diameter tabung kuntum mencapai $17.96 \mathrm{~mm}$ (Gambar 4). Fenologi pemekaran bunga $C$. jamacaru terjadi berdasarkan panjangnya kuntum bunga, terbukanya perianthium dalam atau melebarnya diameter perianthium luar dan bertambahnya diameter kumpulan stamen. Stamen atau benangsari merupakan organ reproduksi jantan pada bunga C. jamacaru yang berwarna putih.

Pembungaan $C$. jamacaru ditandai dengan munculnya kuncup bunga di beberapa batang atau cabang tanaman. Umumnya, dalam satu cabang terdapat 2 hingga 3 kuncup bunga. Bentuk kuncup bunga $C$. jamacaru membulat dengan ujung runcing. Masing-masing kuncup terdiri dari tabung kuntum yang merupakan kesatuan kelopak dan mahkota dengan antera dan stigma berlepasan.

Pengamatan bunga mekar C. jamacaru ini dilakukan setiap 2 jam sekali yang dimulai pada pukul 18:00 WIB sampai dengan pukul 06:00 WIB. Bunga C. jamacaru mulai mekar pada pukul 18:00 WIB dan layu pada pukul 10:00 WIB. Bunga mekar sempurna (antesis) pada pukul 22:00

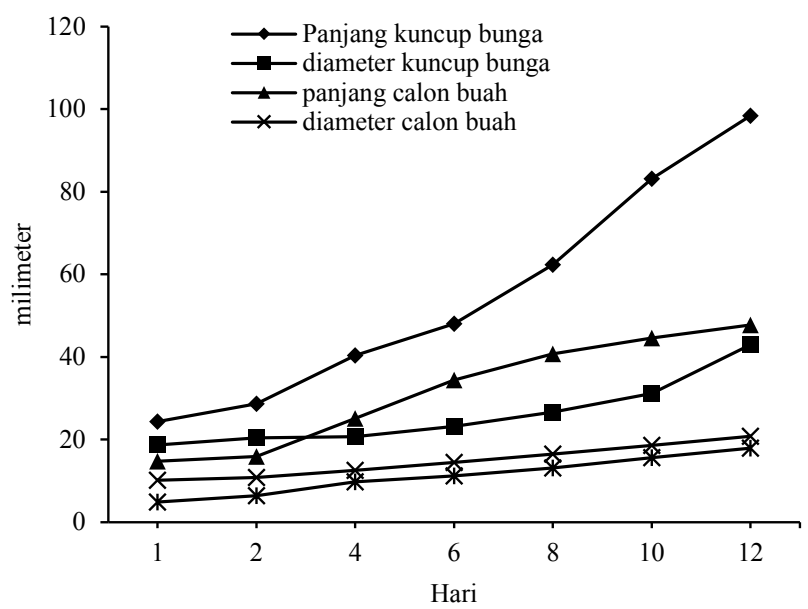

Gambar 4. Pertumbuhan bunga C. jamacaru
-24:00 WIB, kemudian bunga akan layu (Tabel 1). Variabel diameter kumpulan stamen, dan diameter periantium pada pukul 24:00 WIB menunjukkan nilai maksimal yaitu 70.75 mm dan $105.58 \mathrm{~mm}$; kemudian akan layu pada pukul 06:00 WIB ditandai penurunan diameter kumpulan stamen dan diameter periantium yaitu $40.26 \mathrm{~mm}$ dan $80.11 \mathrm{~mm}$. Variabel panjang kuntum pada pukul 18:00 WIB menunjukkan nilai tertinggi yaitu $211.12 \mathrm{~mm}$ kemudian menurun pada pukul 06:00 WIB yaitu $176.77 \mathrm{~mm}$. Pada umumnya, fenologi pembungaan pada keluarga Cactaceae memiliki siklus yang lama, salah satunya adalah $C$. jamacaru mulai mekar pada hari ke-13.

Bunga $C$. jamacaru mulai mekar pada pukul 18.00 WIB diiringi dengan melebarnya diameter periantium dan kumpulan stamen. Mekar sempurna terjadi pada pukul 24.00 WIB sampai pukul 02.00 WIB dini hari. Hal ini ditunjukkan oleh diameter periantium luar mencapai titik lebar maksimum. Setelah itu perianthium dan stamen mulai menutup sampai pukul 04.00 WIB. Bunga mencapai titik layu permanen pukul 06.00 WIB. Antesis dan reseptivitas bunga terjadi pada pukul 19.00-20.00 WIB. Hal ini ditandai dengan serbuk sari menempati permukaan dalam antera yang telah pecah dan pada permukaan percabangan stigma terdapat lendir tipis (reseptif). Perkembangan fenologi bunga dan buah C. jamacaru dapat dilihat pada Gambar 5, mulai dari kuncup hingga mekar sempurna (membutuhkan waktu sekitar 13 hari) kemudian akan layu pada keesokan harinya, dan terbentuk buah. Bunga gugur dua hari setelah mekar dengan kondisi kuntum berwarna hitam (Gambar 5I). Fenologi pemekaran bunga $C$. jamacaru terjadi berdasarkan panjangnya kuntum bunga, terbukanya perianthium dalam dan bertambahnya diameter kumpulan stamen.

Berdasarkan data klimatologi yang bersumber dari BMKG (2020) menunjukkan bahwa koleksi C. jamacaru di Kebun Raya Bogor tumbuh dengan temperatur minimum rata-rata dari bulan Maret sampai dengan Mei 2015 berkisar $25.7{ }^{\circ} \mathrm{C}$, kelembaban minimum rata-rata berkisar $82.5 \%$, curah hujan minimum rata-rata $12.1 \mathrm{~mm}$ sedangkan lama penyinaran matahari minimum rata-rata adalah 4.7 jam (Tabel 2). Faktor lingkungan seperti cahaya dan temperatur sangat mempengaruhi proses pembungaan, pembentukan buah, perkembangan buah hingga matang pada buah naga (Malik et al., 2018). Karakter morfologi buah naga seperti panjang dan diameter buah dipengaruhi oleh variasi 
Tabel 1. Rerata panjang kuntum, diameter periantium dan diameter kumpulan stamen C. jamacaru

\begin{tabular}{lccc}
\hline Pukul & Panjang kuntum $(\mathrm{mm})$ & Diameter periantium $(\mathrm{mm})$ & Diameter kumpulan stamen $(\mathrm{mm})$ \\
\hline 18 & $211.12 \mathrm{a}$ & $0.00 \mathrm{~d}$ & $0.00 \mathrm{~d}$ \\
20 & $203.38 \mathrm{ab}$ & $46.27 \mathrm{~cd}$ & $46.21 \mathrm{~cd}$ \\
22 & $195.60 \mathrm{ab}$ & $78.21 \mathrm{bcd}$ & $57.93 \mathrm{bcd}$ \\
24 & $193.70 \mathrm{bcd}$ & $105.58 \mathrm{a}$ & $70.75 \mathrm{a}$ \\
2 & $192.31 \mathrm{bcd}$ & $103.60 \mathrm{ab}$ & $61.75 \mathrm{ab}$ \\
4 & $183.71 \mathrm{~cd}$ & $90.50 \mathrm{ab}$ & $52.46 \mathrm{ab}$ \\
6 & $176.77 \mathrm{~d}$ & $80.11 \mathrm{bcd}$ & $40.26 \mathrm{bcd}$ \\
\hline
\end{tabular}

Keterangan: Angka-angka yang diikuti huruf yang sama dalam satu kolom menunjukkan tidak berbeda nyata pada taraf uji DMRT 5\%

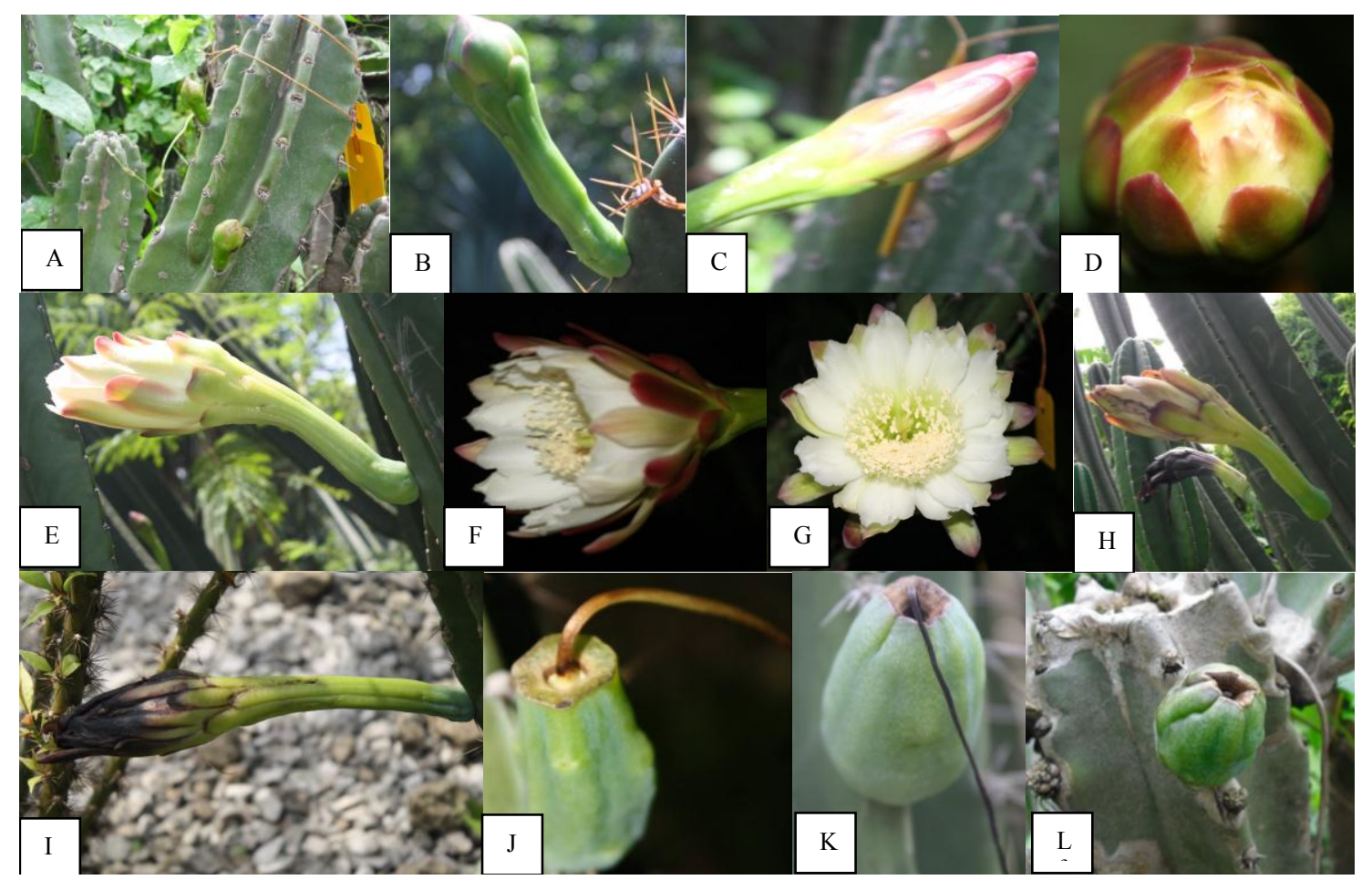

Gambar 5. Tahapan fenologi pembungaan dan pembuahan C. jamacaru (A) kuncup bunga hari ke-2, (B) kuncup bunga hari ke-5, (C) kuncup bunga hari ke-7, (D) kuncup bunga hari ke-7 tampak dari atas, (E) kuncup bunga hari ke- 10, (F) bunga mulai mekar hari ke-12, (G) bunga mekar sempurna hari ke-13, (H) bunga layu hari ke-14, (I) bunga layu hari ke-15, (J) kuntum bunga jatuh dan tersisa calon buah, (K) pembentukan buah muda, (L) buah pada hari ke-20

Tabel 2. Rerata data klimatologi Bogor pada bulan Maret hingga Mei 2015

\begin{tabular}{lcccccc}
\hline Bulan & $\begin{array}{c}\text { Temperatur } \\
\min \left({ }^{\circ} \mathrm{C}\right)\end{array}$ & $\begin{array}{c}\text { Temperatur } \\
\text { maks }\left({ }^{\circ} \mathrm{C}\right)\end{array}$ & $\begin{array}{c}\text { Temperatur } \\
\text { rerata }\left({ }^{\circ} \mathrm{C}\right)\end{array}$ & $\begin{array}{c}\text { Kelembaban } \\
\text { rerata }(\%)\end{array}$ & $\begin{array}{c}\text { Curah hujan } \\
(\mathrm{mm})\end{array}$ & $\begin{array}{c}\text { Lamanya penyinaran } \\
\text { matahari (pukul) }\end{array}$ \\
\hline Maret & 22.3 & 31.3 & 25.7 & 86.0 & 15.9 & 4.7 \\
April & 23.0 & 31.8 & 26.1 & 85.9 & 12.1 & 5.1 \\
Mei & 22.2 & 32.5 & 26.3 & 82.5 & 15.4 & 7.5 \\
\hline
\end{tabular}

Sumber: BMKG (2020)

waktu (musim). Penelitian C. jamacaru yang dilakukan di Brasil, membutuhkan temperatur berkisar $25-30{ }^{\circ} \mathrm{C}$ dalam menunjang keberhasilan perkecambahan biji dan pembenihan (Alencar et al., 2012; Meiado et al., 2010).
Pada penelitian ini teramati beberapa serangga yang mengunjungi bunga $C$. jamacaru, serangga-serangga tersebut dapat berperan sebagai penyerbuk atau pengunjung, diantaranya adalah Trigona fulviventris, Apis indica (lebah) 
dan Camponotus sp. (semut) (Gambar 6). Kunjungan Trigona fulviventris lebih sering terlihat saat menjelang penyerbukan yaitu saat bunga belum mekar sempurna. Serangga Apis indica atau yang lebih dikenal dengan Apis cerana, terlihat membawa polen bunga ini pada malam hari tetapi tidak dapat dipastikan apakah serangga ini menyentuh stigma atau tidak. Keberadaan koloni semut (Camponotus sp.) hampir setiap saat ditemukan pada saat pengamatan, tetapi tidak dapat disimpulkan sebagai serangga penyerbuk karena tidak dilakukan pengamatan lebih lanjut mengenai kegiatan yang dilakukan koloni semut.

Keberadaan semut pada tumbuhan memiliki nilai positif bagi tumbuhan itu sendiri, antara lain sebagai penyerbuk beberapa jenis bunga dan perbaikan siklus hara dalam tanah. Hasil penelitian Sulistiyowati dan Putra (2016), menemukan 25 serangga pada pagi dan malam hari yang berperan sebagai penyerbuk dan pengunjung pada buah naga merah, diantaranya 13 serangga penyerbuk dan 12 serangga pengunjung. Serangga penyerbuk pada pukul 06.00-08.00 WIB yaitu Apis melifera, pada pukul 23.0024.00 WIB yaitu Trichoplusia sp., sedangkan Camponotus spp. dapat ditemukan hampir setiap waktu. Serangga pengunjung yang dapat dijumpai pada pukul 06.00-08.00
WIB yaitu Anax juniusdan serangga yang dapat ditemukan hampir setiap waktu yaitu Pachycandyla sp. Berdasarkan hasil penelitian Rego et al. (2012) pada bunga Cipocereus laniflorus (Cactaceae) yang mekar sempurna pada malam hari menunjukkan bahwa selain kelalawar yang berperan sebagai pollinator utama, ditemukan serangga lainnya yaitu kumbang Nitidulidae dan lebah Trigona fulviventris juga mengunjungi bunga ini dan terlihat membawa polen tetapi tidak terlihat menyentuh stigma. Selain kelalawar dan serangga lainnya, burung kolibri juga terlihat mengumpulkan nektar pada bunga tersebut pada sore hari hingga fajar.

Bunga $C$.jamacaru mekar pada malam hari serta hanya satu malam saja sehingga waktu penyerbukan tergolong cukup singkat. Beberapa faktor yang sangat berperan penting dalam keberhasilan penyerbukan adalah polen (serbuk sari), nectar, dan hewan penyerbuk (polinator) (Almeida et al., 2013). Polinasi pada kaktus umumnya dibantu oleh lebah, tawon, kumbang, kupu-kupu, ngengat, burung dan kelalawar. Serangga yang memiliki kunjungan lebih banyak pada bunga saat polinasi dapat dinyatakan sebagai serangga yang berpotensi sebagai serangga penyerbuk, sedangkan serangga yang kunjungannya sedikit berpotensi sebagai serangga pengunjung.

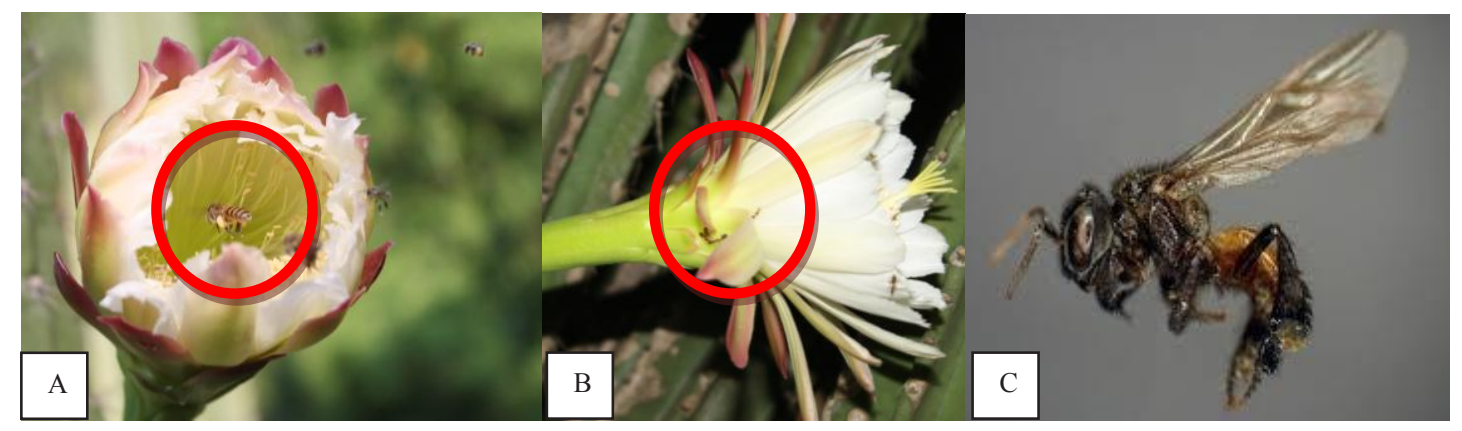

Gambar 6. Serangga yang berperan dalam penyerbukan C. jamacaru (A) Apis indica, (B) semut, (C) Trigona fulviventris

\section{KESIMPULAN}

Fenologi pemekaran bunga C. jamacaru dimulai sejak muncul kuncup bunga sampai bunga mekar selama 9-13 hari. Layu permanen terjadi satu hari setelah bunga mekar sempurna. Antesis dan reseptivitas bunga terjadi pada pukul 19.00-20.00 WIB. Mekar sempurna pada pukul 22.00-24.00 WIB. Serangga yang terlihat berkunjung pada $C$. jamacaru dibantu oleh Apis indica dan semut, sedangkan serangga Trigona berperan sebagai serangga pengunjung. Kebutuhan untuk makan dan perilaku masing-masing species ini yang mempengaruhi serangga-serangga ini untuk datang. Penulis menyarankan untuk dilakukan pengkajian lebih lanjut terhadap viabilitas serbuk sari yang bertujuan untuk menunjang keberhasilan penyerbukan atau persilangan sebagai induk jantan, serta pengkajian lebih lanjut pada lamanya stigma reseptif terhadap polen.

\section{UCAPAN TERIMAKASIH}

Penulis mengucapkan terima kasih kepada Pusat Penelitian Konservasi Tumbuhan dan Kebun Raya-LIPI dan Bapak (alm) Subekti yang telah membantu dalam pengambilan data dan pengamatan pada penelitian ini.

\section{DAFTAR PUSTAKA}

Almeida, O.J.G., J.H. Cota-Sánchez, A.A.S. Paoli. 2013. The systematic significance of floral morphology, nectaries, and nectar concentration in epiphytic cacti of tribes Hylocereeae and Rhipsalideae (Cactaceae). Pers. Plant Ecol. Evol. Syst. 15:255-268. http:// dx.doi.org/10/1016/j.ppees.2013.08.001. 
Alencar, N.L.M., E. Gomes-Filho, R. Innecco. 2012. Cereus jamacaru seed germination and initial seedling establishment as a function of light and temperature conditions. Sci. Agricola 69:70-74. Doi:10.1590/ S0103-90162012000100010.

Anderson, E.F. 2001. The Cactus Family. Timber Press, Portland. Zavo.info/kORP9 [24 Febuari 2021].

[BMKG] Badan Meteorologi, Klimatologi, dan Geofisika. 2020. Data Online Pusat Database BMKG. http:// dataonline.bmkg.go.id [14 Agustus 2020].

Britton, N.L., J.N. Rose. 1920. The Cactaceae, Description and illustration of plants of the Cactus family, Volume II. The Carnegie Institute of Washington, USA. http://publicationsonline.carnegiescience. edu/publications_online/cactaceae/Britton_Rose_ Cactaceae_2.pdf. [12 Maret 2020].

De Lucena, C.M., R.F.P. de Lucena, G.M. Costa, T.K.N. Carvalho, G.G. da Silva Costa, R.R. da Nobrega Alves, D.D. Pereira, J.E. da Silva Ribeiro, C.A.B. Alves, Z.G.M. Quirino, E.N. Nunes. 2013. Use and knowledge of Cactaceae in Northeastern Brazil. J. Ethnobiol. Ethnomed. 9:62. Doi:10.1186/1746-42699-62.

Dutra, J.C., J.B. de Oliveira, P.R. Pereira, J.M. Ferreira, M.C. Batitucci. 2019. Fruiting increases total content of flavonoids and antiproliferative effects of Cereus jamacaru D.C. cladodes in sarcoma 180 cells in vitro. Asian Pac. J. Trop. Biomed. 9:66-72.

Franck, A.R., B. Peguero, W. Cinea, B. Jestrow. 2017. A new spesies of Cereus S. Str. (Cactaceae) endemic to Haiti. Phytoneuron 29:1-17.
Gomes, V.G.N., Z.G.M. Quirino. H.F.P. Araujo. 2014. Frugivory and seed dispersal by birds in Cereus jamacaru DC. ssp. jamacaru (Cactaceae) in the Caatinga of Northeastern Brazail. Braz. J. Biol. 74:3240. http://dx.doi.org/10.1590/1519-6984.15312.

Jordaan, J., T. Mantji. 2012. Biological control of Cereus jamacaru (queen of the night cactus) in the Thornveld of the Limpopo Province, South Africa. Grassroots 12:36-40.

Malik, B., M. Hossain, A. Rahim. 2018. Influences of variety and flowering time on some physio-morphological and chemical traits of dragon fruit (Hylocereus spp.). J. Hortic. Postharvest Res. 1:115-130.

Meiado, M.V., L.S.C. de Albuquerque, E.A. Rocha, M. Rojas-Aréchigas, I.R. Leal. 2010. Seed germination responses of Cereus jamacaru DC. Ssp. Jamacaru (Cactaceae) to environmental factors. Plant Species Biol. 25:120-128. Doi:10.1111/j.14421984.2010.00274.x.

Rego, J.O., E.V. Franceschinelli, D.C. Zappi. 2012. Reproductive biology of a highly endemic species: Cipocereus latiflorus N.P.Taylor\&Zappi (Cactaceae). Acta bot. bras. 26:243-250.

Sulistiyowati, T.I., R.E. Putra. 2016. Perilaku serangga pengunjung buahnaga merah (Hylocereus polyrhizus). Prosiding Seminar Nasional From Basic Science to Comprehensive Education. http://doi.org/10.2425/ psb.v2i1.3340.

Sutton. 2017. Post-release evaluation of the biological control programme against Cereus jamacaru De Candolle (Cactaceae), in South Africa. Thesis. Master of Science. Rhodes University. South Africa, SA. 